in individual members of the control group was unrelated to their gastric acidity. This degree of blood loss has been shown to be remarkably consiant for any individual (Croft and Wood, 1967). It would appear that the control patients with the greater blood loss possess some factor or factors absent in almost all patients with pernicious anaemia as well as in the remaining control patients. Differences in the rate of gastric emptying, gastric mucosal characteristics, or in systemic effects of aspirin may be responsible for the variation in blood loss between individuals.

We are indebted to Mr. K. H. Clarke, physicist-in-charge, Cancer Institute, Melbourne, for allowing us the use of the large volume scintillation detector; to $\mathrm{Mr}$. J. R. Bainbridge, Monash University, for statistical advice; and to the honorary medical staff of Alfred Hospital for permission to study patients admitted under their care.
REFERENCES

Brodie, D. A., and Chase, B. J. (1969). Gastroenterology, 56, 206

Croft, D. N., and Wood, P. H. N. (1967). British Medical fournal, 1, 137.

Davenport, H. W. (1965). Gastroenterology, 49, 189.

Davison, C., Hertig, D. H., and DeVine, R. (1966). Clinical Pharmacology and Therapeutics, 7, 239.

Kay, A. W. (1953). British Medical fournal, 2, 77.

Laws, J. W., and Pitman, R. G. (1960). British fournal of Radiology, 33, 229.

Menguy, R. (1966). Gastroenterology, 51, 430.

Mollison, P. L. (1961). Clinical Science, 21, 21.

Overholt, B. F., and Pollard, H. M. (1968). Gastroenterology, 54, 538.

Pierson, R. N.. jun., Holt, P. R. Watson, R. M., and Keating, R. P. (1961). N.. jun., Holt, P. R., Watson, R. M.

Roche, M., Perez-Gimenez, M. E., Layrisse, M., and Di Prisco, E. (1957). Fournal of Clinical Investigation, 36, 1183.

Schilling, R. F. (1953). Fournal of Laboratory und Clinical Medicine, 42, 860 .

Winkelman, E. I., and Summerskill, W. H. J. (1961). Gastroenterology, 40, 56.

Wood, I. J., Doig, R. K., Motteram, R., and Hughes, A. (1949). Lancet, 1,18

Wood, P. H. N., Harvey-Smith, E. A., and Dixon, A. St.J. (1962). British Medical fournal, 1, 669

\title{
Effect of Controlled Oxygen Therapy on Arterial Blood Gases in Acute Respiratory Failure
}

\author{
D. A. WARRELL, ${ }^{*}$ B.M., M.R.C.P. ; R. H. T. EDWARDS, ${ }^{*}$ M.B., PH.D., M.R.C.P. ; S. GODFREY, $\ddagger$ M.B., PH.D., M.R.C.P. \\ N. L. JONES, $†$ M.D., M.R.C.P.
}

British Medical fournal, 1970, 2, 452-455

\begin{abstract}
Cummary: Seven patients in acute exacerbation of chronic respiratory failure were given $24.5 \%$ and later $28 \%$ oxygen through Ventimasks. The mean increases in arterial $\mathrm{PO}_{2}$ were 11 and $21 \mathrm{~mm}$. $\mathrm{Hg}$ while breathing $24.5 \%$ and $28 \%$ oxygen respectively compared with control values while breathing air. Associated increases in arterial $\mathrm{PCO}_{2}$ were 4 and $8 \mathrm{~mm}$. $\mathrm{Hg}$, respectively. In five of the patients these increases in inspired oxygen concentration resulted in useful increases in tissue oxygen supply without significant deterioration in ventilation, but in two patients arterial $\mathrm{PCO}_{2}$ rose excessively and artificial ventilation was required.
\end{abstract}

\section{Introduction}

An essential part of the management of respiratory failure occurring in patients with chronic airway obstruction is the relief of hypoxia by increasing inspired oxygen concentration. Campbell (1965) suggested that the continuous administration of $24.5 \%$ or $28 \%$ oxygen might be expected to increase arterial oxygen saturation and tissue oxygen supply by a useful amount with less risk of decreasing ventilation than would be incurred by the use of higher concentrations of oxygen. The present paper reports a study of the effect of $24.5 \%$ and $28 \%$ oxygen administration to patients admitted to hospital with acute respiratory failure. The object was to document the improvement in arterial $\mathrm{PO}_{2}$, study the time course of any changes, and examine the effect on arterial $\mathrm{PCO}_{2}$.

\section{Methods}

Patients.-The seven patients were chronic bronchitics (Medical Research Council, 1965). In five of them, who had been attending an outpatient clinic for cases of respiratory disease, previous values for forced expired volume in the first second (F.E.V.1) had been less than $50 \%$ of predicted normal (Cotes, 1965), indicating chronic severe airway obstruction,

* Medical Registrar, Hammersmith Hospital. London W.12.

†Honorary Lecturer, Royal Postgraduate Medical School, London W.12. Present address: St. Joseph's Hospital, Hamilton, Ontario.

$\neq$ Present address: Institute for Diseases of the Chest, Brompton Hospital, London S.W.3. and rebreathing mixed venous $\mathrm{PCO}_{2}\left(\mathrm{P} \overline{\mathrm{v}} \mathrm{CO}_{2}\right)$ (Campbell and Howell, 1960) had been persistently raised, indicating chronic respiratory failure (Table I). They were admitted to hospital during an exacerbation of symptoms associated with evidence of acute worsening of respiratory failure; $\mathrm{P}_{\bar{v}} \mathrm{CO}_{2}$ was above 65 $\mathrm{mm}$. $\mathrm{Hg}$ and at least $15 \mathrm{~mm}$. $\mathrm{Hg}$ higher than the values obtained in the outpatient clinic.

\section{Management}

None of the patients had received oxygen therapy on their way to hospital; they were seen in the emergency department, being accepted into the study on the basis of a clinical assessment and measurement of $\mathrm{P}_{\bar{v}} \mathrm{CO}_{2}$. The patients were moved to the ward and standard treatment with antibiotics, bronchodilators, and diuretics was instituted. Their cooperation in the study was obtained by informed consent. A Teflon cannula was inserted percutaneously into a radial artery and flushed at 15-minute intervals with small amounts of heparinized saline. Blood was sampled for the measurement of arterial gas tensions $\left(\mathrm{PaO}_{2}, \mathrm{PaCO}_{2}\right)$ and lactate concentration, plasma bicarbonate and electrolyte concentrations, blood urea, serum lactic dehydrogenase activity, haemoglobin, packed cell volume, and leucocyte count. After 30 minutes blood gas tensions were again measured. The patients were then started on oxygen through a $24 \%$ Ventimask (Vickers Medical) (Campbell and Gebbie, 1966). Blood gas tensions were measured 15, 30, 60, 120, and 150 minutes later and lactate was measured at 60 minutes. A $28 \%$ Ventimask was substituted at 150 minutes and measurements were repeated $15,30,60$, and 120 minutes later.

The oxygen concentrations produced by Ventimasks were measured in the laboratory with a mass spectrometer (Campbell and Gebbie, 1966). Nominally $24 \%$ masks delivered a mean inspired concentration of 24.3 (S.D. 0.3 ) $\%$ oxygen, and $28 \%$ masks a mean of 28.2 (S.D. 0.4 ) $\%$ oxygen; values of $24.5 \%$ and $28 \%$, respectively, were assumed in the present study. During the study routine observations of clinical state were made and recorded; these included the ability to cough and produce sputum either spontaneously or with help, a measure of the mental state, blood pressure, and heart rate. A portable chest radiograph and an electrocardiogram (E.C.G.) were taken as soon as possible after admission. 


\section{Analytical Techniques}

Arterial blood was sampled anaerobically in heparinized glass syringes and was analysed within five minutes. $\mathrm{PO}_{2}$ was measured with a Beckman macroelectrode and $\mathrm{PCO}_{2}$ with a Severinghaus electrode, calibrated with gases previously analysed in the Lloyd-Haldane apparatus. The S.D. of duplicate measurements was $0.3 \mathrm{~mm}$. $\mathrm{Hg}$. Tonometry experiments were performed during the period in which the studies were made; the $95 \%$ confidence limits for measurements of $\mathrm{PO}_{2}$ were $\pm 1.5 \mathrm{~mm} . \mathrm{Hg}$ and of $\mathrm{PCO}_{2} \pm 1 \mathrm{~mm} . \mathrm{Hg}$. Values for arterial oxygen saturation $\left(\mathrm{SaO}_{2}\right)$ were derived from $\mathrm{Po}_{2}$ and $\mathrm{PCO}_{2}$ by means of the computer table prepared by Ball and Shephard (Denison, 1968). Ideal alveolar to arterial $\mathrm{PO}_{2}$ difference $\left(\mathrm{PA}-\mathrm{aO}_{2}\right)$ and pulmonary venous admixture (Q́va/Q்t) were calculated (see Table III), assuming values of 0.8 for respiratory exchange ratio and $5 \mathrm{ml} .100 \mathrm{ml}$. for arteriovenous oxygen content difference. Plasma bicarbonate was measured with a Natelson microgasometer (Scientific Industries, Model 600), and arterial $p H$ was then derived by use of the Henderson-Hasselbalch equation, assuming a value of 6.10 for $\mathrm{p} K^{\prime}$ (Sinclair et al., 1968). Arterial lactate concentration was measured by an enzymatic method (Boehringer and Soehne, Mannheim, West Germany); the S.D. of duplicate estimates was $0.17 \mathrm{mM} / 1$. Haemoglobin was measured by the cyanmethaemoglobin method; plasma electrolytes, blood urea, and lactic dehydrogenase were measured with an autoanalyser.

\section{Results}

Severe hypoxaemia was present during the initial period of air-breathing; the range of $\mathrm{PaO}_{2}$ was between 25 and 38 mm. $\mathrm{Hg}$ (Fig. 1). There was a moderate degree of hypercapnia, $\mathrm{PaCO}_{2}$ ranging from 55 to 76 ; all but one patient had values for $\mathrm{PaCO}_{2}$ of over $65 \mathrm{~mm}$. $\mathrm{Hg}$. The patients were in a steady state before the administration of oxygen, $\mathrm{PaO}_{2}$ and $\mathrm{PaCO}_{2}$ changing less than $2 \mathrm{~mm}$. $\mathrm{Hg}$ over the first 30 minutes in most cases. $\mathrm{PaO}_{2}$ increased after 15 minutes of $24.5 \%$ oxygen but little further change at 30 minutes. The values for $\mathrm{PaO}_{2}$ obtained from each patient 60 and 120 minutes after starting oxygen were compared with the average of the two control values breathing air. The mean increase in $\mathrm{PaO}_{2}$ for the group of seven patients with $24.5 \%$ oxygen was $10.9 \mathrm{~mm}$. $\mathrm{Hg}$ (range 6.7-17.9, S.D. $4.0 \mathrm{~mm}$. Hg) (Fig. 2, Table II). The corresponding increase in $\mathrm{SaO}_{2}$ was $16.4 \%$ (range 12 to 25, S.D. 4.6). The $\mathrm{PaCO}_{2}$ increased in all but one patient, the average rise being $4.3 \mathrm{~mm}$. $\mathrm{Hg}$ (range -1.2 to +9.3, S.D. $3.42 \mathrm{~mm} . \mathrm{Hg}$ ) (Table II).

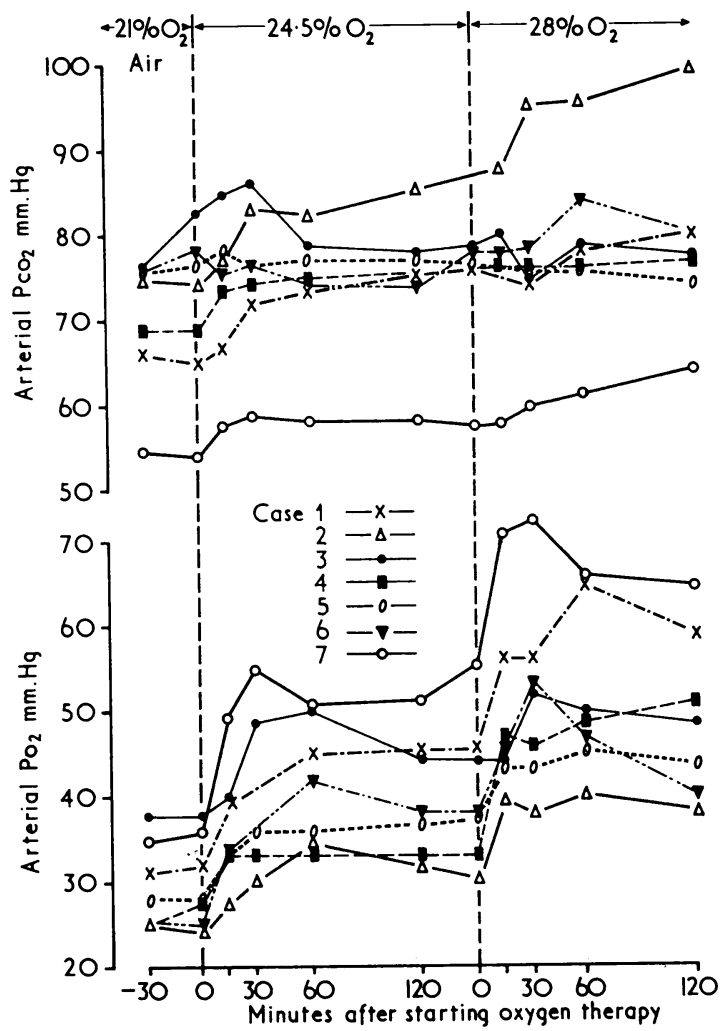

Fig. 1.-Values for arterial blood gas tensions during the first five hours Fig. 1.- Values for arterial blood gas tensions during the first five hours breathing air and $24.5 \%$ and $28 \%$ oxygen by Ventimask.

TABLE I.-Clinical Information About Seven Patients with Acute Respiratory Failure

\begin{tabular}{|c|c|c|c|c|c|c|c|c|}
\hline \multirow{2}{*}{$\begin{array}{l}\text { Case } \\
\text { No. }\end{array}$} & \multirow[b]{2}{*}{ Age } & \multirow[b]{2}{*}{ Sex } & \multicolumn{5}{|c|}{$\begin{array}{l}\text { Pulmonary Function before Exacerbation of Symptoms. } \\
\text { Time of Measurement (Months) before Admission in Parentheses }\end{array}$} & \multirow{2}{*}{ Clinical Course } \\
\hline & & & $\begin{array}{l}\text { F.E.V.1 } \\
\text { (1.). } \\
\text { B.T.S. }\end{array}$ & $\begin{array}{l}\text { v.C. } \\
\text { B.T.P.S. }\end{array}$ & $\begin{array}{l}\text { F.E.V. } \\
(\%)\end{array}$ & 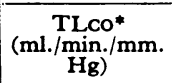 & $\begin{array}{c}\mathrm{P} \overline{\mathrm{c}} \mathrm{CO}_{\mathbf{2}} \\
(\mathrm{mm} . \mathrm{Hg})\end{array}$ & \\
\hline 1 & 54 & F. & 0.32 & 1.53 & $21(6)$ & $3 \cdot 3(1)$ & $57(6)$ & $\begin{array}{l}\text { Artificial ventilation } 8 \text { hours after admission. Developed } \\
\text { surgical emphysema. Died } 6 \text { days after admission }\end{array}$ \\
\hline 2 & 65 & F. & \multicolumn{5}{|c|}{ No values available } & Artificial ventilation 6 hours after admission. Dis- \\
\hline $\begin{array}{l}3 \\
4 \\
5 \\
6 \\
7\end{array}$ & $\begin{array}{l}56 \\
66 \\
71 \\
58 \\
70\end{array}$ & $\begin{array}{l}\mathrm{F} \\
\mathrm{M} \\
\mathrm{M} \\
\mathrm{M}\end{array}$ & $\begin{array}{l}1.08 \\
0.50 \\
0.55 \\
0.90\end{array}$ & $\begin{array}{l}2 \cdot 25 \\
1 \cdot 70 \\
1 \cdot 70 \\
2 \cdot 10\end{array}$ & $\begin{array}{l}\quad 48(5) \\
29(1) \\
32(4) \\
43(7) \\
\text { No values available }\end{array}$ & $\begin{array}{c}18.9(8) \\
9 \cdot 2(20) \\
20.0(6) \\
13.8(24)\end{array}$ & $\begin{array}{l}43(5) \\
66(1) \\
61(4) \\
66(7)\end{array}$ & 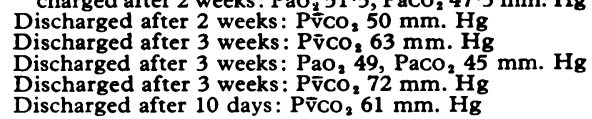 \\
\hline
\end{tabular}

*Carbon monoxide uptake (single breath method).

B.T.P.S. = Body temperature, pressure, and saturation.

TABle II.-Mean Values (and 1 S.D.) for Measured Blood Gas Tensions $\left(\mathrm{PaCO}_{2}, \mathrm{PaO}_{2}\right)$, Derived Oxygen Saturation $\left(\mathrm{SaO}_{2}\right)$ and Calculated Alveolar to Arterial $\mathrm{PO}_{2}$ Difference $\left(P A-a \mathrm{O}_{2}\right)$ and Pulmonary Venous Admixture $(\dot{Q} v a / \dot{Q} t)$ in Seven Patients with Acute Respiratory Failure

\begin{tabular}{|c|c|c|c|c|c|c|c|c|c|c|c|c|c|c|c|c|c|}
\hline \multicolumn{7}{|c|}{ Variable } & \multicolumn{2}{|c|}{$\operatorname{Air}\left(20.9 \% \mathrm{O}_{2}\right)$} & \multicolumn{5}{|c|}{$24 \cdot 5 \% \mathrm{O}_{2}$} & \multicolumn{4}{|c|}{$28 \% \mathrm{O}_{2}$} \\
\hline Time (minutes) & $\cdots$ & .. & $\ldots$ & .. & . & & -30 & $\stackrel{0}{0}$ & +15 & 30 & $\begin{array}{l}60 \\
73 \cdot 8\end{array}$ & 120 & $\begin{array}{l}150(0) \\
75.6\end{array}$ & $\begin{array}{l}+15 \\
76 \cdot 2\end{array}$ & $\begin{array}{l}30 \\
76 \cdot 4\end{array}$ & $\begin{array}{l}60 \\
78.5\end{array}$ & $\begin{array}{l}120 \\
78.9\end{array}$ \\
\hline $\mathrm{PaCO}_{2}(\mathrm{~mm} . \mathrm{Hg})$ & . & .. & $\cdots$ & .. & .. & $\left\{\begin{array}{l}\text { Mean } \\
1 \text { S.D. }\end{array}\right.$ & $\begin{array}{r}70 \cdot 2 \\
7.7\end{array}$ & $\begin{array}{r}71 \cdot 2 \\
9 \cdot 4\end{array}$ & $\begin{array}{r}73.7 \\
8.6 \\
\end{array}$ & $\begin{array}{r}75 \cdot 2 \\
8 \cdot 7\end{array}$ & $\begin{array}{r}73.8 \\
8.3\end{array}$ & $\begin{array}{l}70.0 \\
10.6\end{array}$ & $\begin{array}{r}75.6 \\
8.9\end{array}$ & $\begin{array}{r}76 \cdot 2 \\
9 \cdot 1\end{array}$ & $\begin{array}{l}76 \cdot 4 \\
10 \cdot 3\end{array}$ & $\begin{array}{l}78.5 \\
10 \cdot 3\end{array}$ & $\begin{array}{l}78.9 \\
10.5\end{array}$ \\
\hline $\mathrm{PaO}_{2}(\mathrm{~mm} . \mathrm{Hg})$ & . & .. &.. & .. & .. & $\begin{array}{l}\text { Mean } \\
\text { S.D. }\end{array}$ & $\begin{array}{r}29 \cdot 8 \\
4.9\end{array}$ & $\begin{array}{r}29 \cdot 8 \\
5 \cdot 3\end{array}$ & $\begin{array}{r}36.7 \\
6.8\end{array}$ & $\begin{array}{r}40 \cdot 3 \\
8 \cdot 8\end{array}$ & $\begin{array}{r}43 \cdot 0 \\
7 \cdot 1\end{array}$ & $\begin{array}{r}44.4 \\
6.9\end{array}$ & $\begin{array}{r}40 \cdot 6 \\
8 \cdot 7\end{array}$ & $\begin{array}{l}49 \cdot 7 \\
10 \cdot 8\end{array}$ & $\begin{array}{l}51 \cdot 6 \\
11.4\end{array}$ & $\begin{array}{r}51.9 \\
9.9\end{array}$ & $\begin{array}{l}49.7 \\
9.8\end{array}$ \\
\hline $\mathrm{SaO}_{2}$ (\% sat.) & . & .. & .. & .. & .. & $\begin{array}{l}\text { Mean } \\
\text { S.D. }\end{array}$ & $\begin{array}{l}48 \cdot 0 \\
10 \cdot 4\end{array}$ & $\begin{array}{l}48 \cdot 0 \\
11.3\end{array}$ & $\begin{array}{l}59.7 \\
10.5\end{array}$ & $\begin{array}{l}63 \cdot 4 \\
12 \cdot 0\end{array}$ & $\begin{array}{r}68.0 \\
9.5\end{array}$ & $\begin{array}{r}71 \cdot 0 \\
9 \cdot 5\end{array}$ & $\begin{array}{l}64 \cdot 1 \\
12 \cdot 2\end{array}$ & $\begin{array}{r}74 \cdot 1 \\
9 \cdot 6\end{array}$ & $\begin{array}{r}76 \cdot 3 \\
9 \cdot 5\end{array}$ & $\begin{array}{r}76 \cdot 7 \\
8 \cdot 9\end{array}$ & $\begin{array}{l}74 \cdot 3 \\
10 \cdot 0\end{array}$ \\
\hline $\mathrm{PA}-\mathrm{aO}_{2}$ & .. & . & . & $\ldots$ & $\ldots$ & $\left\{\begin{array}{l}\text { Mean } \\
S . D\end{array}\right.$ & $\begin{array}{r}34.5 \\
8.3\end{array}$ & $\begin{array}{l}33.3 \\
10.4\end{array}$ & $\begin{array}{r}48.7 \\
7.0\end{array}$ & $\begin{array}{r}43.7 \\
9.1\end{array}$ & $\begin{array}{r}43 \cdot 6 \\
8.1\end{array}$ & $\begin{array}{r}45.9 \\
6.8\end{array}$ & $\begin{array}{r}42.8 \\
5.1\end{array}$ & $\begin{array}{r}58.9 \\
5.9\end{array}$ & $56 \cdot 6$ & $\begin{array}{r}53.9 \\
8.6\end{array}$ & $\begin{array}{l}55.9 \\
10.8\end{array}$ \\
\hline$\dot{\mathrm{Q} v a} / \dot{\mathrm{Q}} \mathrm{t}(\%) \ldots$ & .. & .. & .. & .. & .. & $\begin{array}{l}\text { Mean } \\
\text { S.D. }\end{array}$ & $\begin{array}{r}61 \\
7\end{array}$ & $\begin{array}{r}60 \\
9\end{array}$ & $\begin{array}{r}57 \\
8\end{array}$ & $\begin{array}{l}52 \\
12\end{array}$ & $\begin{array}{r}51 \\
9\end{array}$ & $\begin{array}{l}48 \\
10\end{array}$ & $\begin{array}{l}52 \\
10\end{array}$ & $\begin{array}{l}46 \\
12\end{array}$ & $\begin{array}{l}44 \\
12\end{array}$ & $\begin{array}{l}43 \\
11\end{array}$ & $\begin{array}{l}46 \\
12\end{array}$ \\
\hline
\end{tabular}




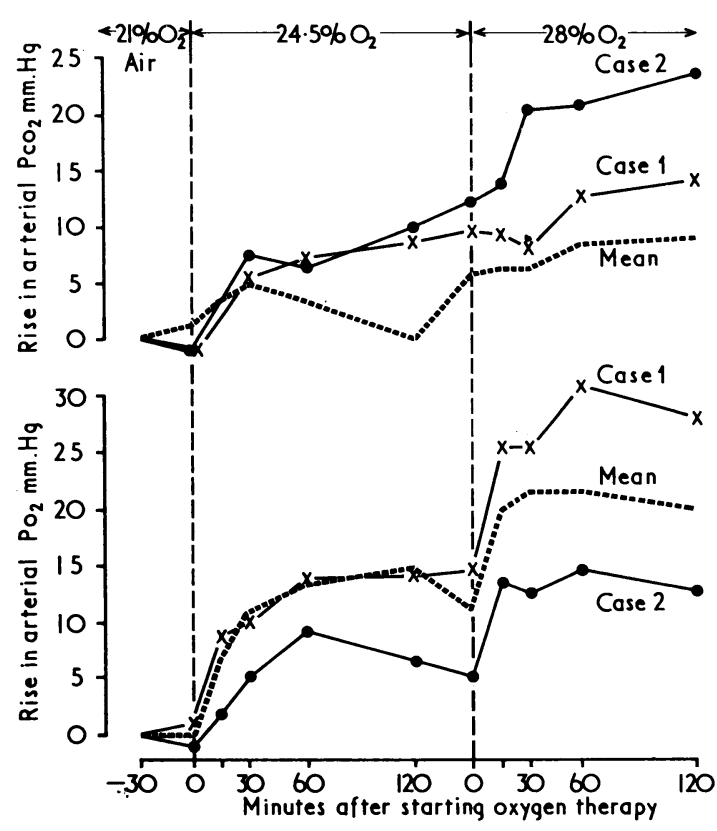

FIG. 2.-Changes in arterial blood gas tensions from initial values (at -30 minutes) during the first five hours of hospital admission in the two patients who eventually required artificial ventilation compared with the mean values for the whole group of seven patients.

Administration of $28 \%$ oxygen led to a further increase in $\mathrm{PaO}_{2}$ to an average of $21.4 \mathrm{~mm}$. $\mathrm{Hg}$ above control levels while breathing air (range 12.9 to 33.3 , S.D. $7.6 \mathrm{~mm}$. $\mathrm{Hg}$ ); the increase in $\mathrm{SaO}_{2}$ averaged $26.3 \%$ (range 15 to 35, S.D. $6.2 \%$ ) (Table II). In five patients there was little change in $\mathrm{PCO}_{2}$ above that obtained during the breathing of $24.5 \%$ oxygen; in the other two patients, both of whom had shown the highest increases during the $24.5 \% \quad \mathrm{O}_{2}$ breathing, the $\mathrm{PCO}_{2}$ rose to 11.8 and $22.2 \mathrm{~mm}$. $\mathrm{Hg}$ above control values. The average increase in $\mathrm{PCO}_{2}$ during $28 \%$ breathing was $7.7 \mathrm{~mm}$. $\mathrm{Hg}$ above control values (range -0.6 to $+22 \cdot 2$, S.D. $7.40 \mathrm{~mm}$. $\mathrm{Hg}$ ) (Table II). Calculated arterial $\mathrm{pH}$ on admission ranged between 7.23 and 7.39 at a time when arterial lactate con- centration ranged between 1.02 and $1.67 \mathrm{mM} / 1$. (Table III). After the patients had breathed $24.5 \%$ oxygen for 60 minutes, lactate had fallen by an average of $0.32 \mathrm{mM} / 1$. (changes ranged from +0.08 to $-0.71 \mathrm{mM} / \mathrm{l}$.)

Serum lactic dehydrogenase and its heat-stable fraction were within the normal range in all cases. In four patients the haemoglobin concentration was above $16 \mathrm{~g} . / 100 \mathrm{ml}$. Radiographical changes consistent with bronchopneumonia were seen in four patients, and cardiac enlargement was seen in four. In three patients the main pulmonary arteries were prominent (Table III). There was E.C.G. evidence of right atrial or ventricular hypertrophy, or both, in four patients. Two patients had atrial arrhythmias (Table III).

Clinical Course (Table I).- The condition of five patients (Cases 3-7) improved so that they were fit to be discharged after 10 days to three weeks in hospital. Their blood gases on discharge indicated improved ventilation compared with the day of admission. In the two patients (Cases 1 and 2) whose $\mathrm{PaCO}_{2}$ increased markedly during oxygen therapy the level of consciousness decreased progressively despite vigorous conservative measures, including physiotherapy and analeptic drugs. Assisted ventilation via endotracheal tube was required. One (Case 2) was discharged, well, after two weeks, but the other (Case 1) had a complicated clinical course and died six days after admission (Table I).

\section{Discussion}

McNicol and Campbell (1965) found that patients with long-standing airway obstruction who presented with acute respiratory failure were severely hypoxaemic and moderately hypercapnic: $\mathrm{PaO}_{2}$ was between 20 and $40 \mathrm{~mm}$. $\mathrm{Hg}$ in $78 \%$ and $\mathrm{PaCO}_{2}$ was between 60 and 80 in $74 \%$. Blood gas tensions in our patients, before active therapy had been started, fell within these ranges. A major problem in such patients is the relief of hypoxaemia without worsening the degree of hypercapnia, which can lead to coma (Westlake et al., 1955). Campbell (1960) pointed out that in these patients useful increases in arterial oxygen saturation result from small increases in arterial oxygen pressure. Such modest increases in arterial oxygen pressure can be achieved by relatively small increases in inspired oxygen concentration whose use should minimize the degree of respiratory depression asso-

TABLE III.-Result of Investigations in Seven Patients with Acute Respiratory Failure on Admission to Hospital

\begin{tabular}{|c|c|c|c|c|c|c|c|c|c|c|c|c|c|c|c|}
\hline \multirow{2}{*}{$\begin{array}{l}\text { Case } \\
\text { No. }\end{array}$} & \multirow{2}{*}{ 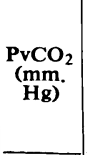 } & \multirow{2}{*}{$\begin{array}{c}\text { Arterial } \\
\text { Bicar- } \\
\text { bonate } \\
\text { Conc. } \\
\text { (mM/l.) }\end{array}$} & \multirow{2}{*}{$\underset{D \mathrm{H}}{\text { Arterial }}$} & \multicolumn{2}{|c|}{$\begin{array}{l}\text { Arterial Lactate } \\
\text { Conc. }(\mathrm{m} \mathrm{M} / 1 .)\end{array}$} & \multicolumn{3}{|c|}{$\begin{array}{l}\text { Plasma Electrolyte } \\
\text { Conc. }(\mathrm{mN})\end{array}$} & \multirow{2}{*}{$\begin{array}{l}\text { Blood Urea } \\
\text { (mg./100 ml.) }\end{array}$} & \multirow{2}{*}{ (i.u. $/ 100 \mathrm{ml}$.) } & \multirow{2}{*}{$\underset{(\mathrm{g} / 100 \mathrm{ml} .)}{\mathrm{Hb}}$} & \multirow{2}{*}{$\begin{array}{l}\text { P.C.V. } \\
\text { (\%) }\end{array}$} & \multirow{2}{*}{$\begin{array}{l}\text { Leucocyte } \\
\text { Count } \\
\text { (cells/ } \\
\text { cu. mm.) }\end{array}$} & \multirow{2}{*}{$\begin{array}{c}\text { Chest } \\
\text { Radiogram }\end{array}$} & \multirow[b]{2}{*}{ E.C.G. } \\
\hline & & & & $\begin{array}{c}\text { Breath- } \\
\text { ing } \\
\text { Air }\end{array}$ & \begin{tabular}{|l|} 
After 1 \\
hour of \\
$24.5 \%$ \\
oxygen
\end{tabular} & $\mathbf{N a}$ & $\mathbf{K}$ & $\mathrm{Cl}$ & & & & & & & \\
\hline \multicolumn{6}{|c|}{ Laboratory Normal range: } & 136-149 & $3 \cdot 8-5 \cdot 2$ & $100-107$ & $14-38$ & $50-170(30-60 \%)^{*}$ & & & & & \\
\hline \multirow[t]{2}{*}{1} & 77 & $33 \cdot 8$ & $7 \cdot 32$ & 1.49 & 0.90 & 135 & $5 \cdot 3$ & 89 & 98 & - & 18.6 & 61 & 5,000 & \begin{tabular}{c|} 
Cardiomegaly. \\
prominent P.A...
\end{tabular} & $\begin{array}{l}\text { R.A.H. } \\
\text { R.V.H. }\end{array}$ \\
\hline & - & 38.5 & $7 \cdot 32$ & 1.67 & 1.28 & 136 & 4.9 & 88 & 72 & $105(50 \%)$ & $16 \cdot 3$ & 57 & 6,000 & $\mid \begin{array}{c}\text { Darominent P.A... } \\
\text { basal con- } \\
\text { solidation }\end{array}$ & $\begin{array}{c}\text { Atrial } \\
\text { ectopic } \\
\text { beats } \\
\text { R.A.H. }\end{array}$ \\
\hline 3 & 81 & $33 \cdot 3$ & $7 \cdot 25$ & 1.02 & $1 \cdot 10$ & 136 & $5 \cdot 0$ & 94 & 85 & $165(60 \%)$ & $15 \cdot 0$ & 51 & 7,000 & Cardiomegaly & $\begin{array}{l}\text { R.V.H. } \\
\text { Atrial } \\
\text { fibrilla- } \\
\text { tion }\end{array}$ \\
\hline 4 & 81 & $42 \cdot 1$ & $7 \cdot 39$ & 1.54 & 0.83 & 141 & $2 \cdot 8$ & 82 & 52 & $125(65 \%)$ & $12 \cdot 2$ & 43 & 9,000 & $\begin{array}{c}\text { Cardiomegaly, } \\
\text { pleural } \\
\text { effusion }\end{array}$ & Normal \\
\hline \multirow[t]{3}{*}{5} & 81 & $31 \cdot 3$ & $7 \cdot 23$ & 1.25 & $1 \cdot 10$ & 137 & $4 \cdot 0$ & 88 & 27 & $120(45 \%)$ & 16.5 & 53 & 8,000 & $\begin{array}{l}\text { Basal } \\
\text { consolidation }\end{array}$ & Normal \\
\hline & 86 & $33 \cdot 8$ & $7 \cdot 26$ & $1 \cdot 35$ & 1.22 & 136 & $4 \cdot 6$ & 90 & 146 & - & 16.5 & 55 & 13,000 & $\begin{array}{l}\text { Cardiomegaly, } \\
\text { prominent } \\
\text { P.A., lobar } \\
\text { consolidation }\end{array}$ & R.V.H. \\
\hline & 70 & $30 \cdot 0$ & $7 \cdot 35$ & - & - & 137 & 4.6 & 90 & 36 & $170(40 \%)$ & $14 \cdot 6$ & 48 & 17,000 & $\begin{array}{c}\text { Long-standing } \\
\text { extensive } \\
\text { fibrosis (old } \\
\text { tuberculosis) }\end{array}$ & R.A.H. \\
\hline
\end{tabular}


ciated with relief of hypoxaemia. We have confirmed these observations. In our patients an increase in the inspired oxygen pressure of $25 \mathrm{~mm}$. $\mathrm{Hg}$ produced with $24.5 \%$ oxygen led to an average increase of $11 \mathrm{~mm} . \mathrm{Hg}$ in $\mathrm{PaO}_{2}$ and of $16 \%$ in $\mathrm{SaO}_{2}$. This increase in oxygen saturation represents an increase of about $200 \mathrm{ml} . / \mathrm{min}$. in the oxygen available to the tissues at a cardiac output of $61 \mathrm{ml} . / \mathrm{min}$., an increase sufficient to supply the basal needs for oxygen (Campbell, 1967). A further increase of $25 \mathrm{~mm}$. $\mathrm{Hg}$ in the inspired oxygen pressure by administration of $28 \%$ oxygen led to increases of $10 \mathrm{~mm} . \mathrm{Hg}$ in $\mathrm{PaO}_{2}$ and $10 \%$ in $\mathrm{SaO}_{2}$ over and above those obtained while breathing $24.5 \%$ oxygen.

Though $\mathrm{SaO}_{2}$ was on average less than $50 \%$ before the start of oxygen therapy there was little biochemical evidence of tissue hypoxia. Arterial lactate concentrations were only marginally raised, but they had fallen after administration of $24.5 \%$ oxygen for 60 minutes. Higher arterial lactate levels were reported by Penman (1962) in patients with acute exacerbations of chronic bronchitis. Values ranged between 0.8 and $6.2 \mathrm{mM} / 1$. while breathing air and fell by an average of $0.5 \mathrm{mM} / 1$. after 15 minutes of breathing $100 \%$ oxygen. Penman's patients were generally less hypoxaemic than ours. It is possible that the manometric method which he used to estimate lactate gave higher values than the enzyme method used by us. Serum lactic dehydrogenase levels were normal in our patients as in most of Refsum's (1963) patients who had acute exacerbations of chronic respiratory failure. Refsum found that serum aspartate and alanine aminotransferases were raised in some patients who had a normal lactic dehydrogenase.

Comparison of the results of the present study with those reported by other authors is complicated by differences in the method of administering oxygen and in the clinical condition of the patients with chronic airways obstruction. Schiff and Massaro (1967) observed a mean increase of $11 \mathrm{~mm}$. $\mathrm{Hg}$ in $\mathrm{PaO}_{2}$ after changing from air to $24.5 \%$ oxygen by Ventimask in patients who were not acutely ill. Mithoefer et al. (1967) gave oxygen by Ventimask to patients who were clinically stable and also to those in respiratory failure. Their procedure was not standardized, however, and a wide range of $\mathrm{PaO}_{2}$ changes were observed. Hutchison et al. (1964) administered oxygen by the Edinburgh mask to patients with acute respiratory failure. The inspired oxygen concentrations were generally higher than those used in the present study and no fixed sequence was employed. The overall relationship between $\mathrm{PaO}_{2}$ and inspired oxygen concentration $\left(\mathrm{FIO}_{2}\right)$ was an increase of $2.08 \mathrm{~mm}$. $\mathrm{Hg} \mathrm{PaO}$ for each $1 \%$ increase in $\mathrm{FIO}_{2}$ which is less than the value of $3.3 \mathrm{~mm}$. $\mathrm{Hg} / 1 \%$ calculated from the maximum increase in $\mathrm{PaO}_{2}$ after $24.5 \%$ and $28 \%$ oxygen in our patients. The increases in $\mathrm{PaO}_{2}$ after oxygen administration were associated with increases in $\mathrm{PaCO}_{2}$. With $24.5 \%$ oxygen these were small in degree, amounting on an average to less than $5 \mathrm{~mm}$. $\mathrm{Hg}$, an insignificant worsening in the degree of hypercapnia; this compares with an average value of $2 \mathrm{~mm}$. $\mathrm{Hg}$ obtained by Schiff and Massaro (1967). The increases were more pronounced with $28 \%$ oxygen, amounting to about $8 \mathrm{~mm}$. $\mathrm{Hg}$ above the $\mathrm{PaCO}_{2}$ during air breathing. There was some variation in the response of individual patients; it is noteworthy that the two patients showing the greatest increases in $\mathrm{PaCO}_{2}$ eventually required endotracheal intubation and intermittent positive-pressure breathing in order to counteract their worsening respiratory failure.

The presence of severe abnormalities in the distribution of ventilation and perfusion in the lungs of these patients limited the increase in $\mathrm{PaO}_{2}$ to less than half of the increase in inspired $\mathrm{Po}_{2}$. If there was no change in the cardiac output and respiratory exchange ratio, we may calculate the change in venous admixture ratio, using the average values obtained in our studies. These calculations (Table II) imply that much of the total cardiac output, amounting to $60 \%$, was effectively bypassing gas-exchanging parts of the lung while the patients were breathing air; this proportion fell to $50 \%$ during the breathing of $24.5 \% \quad \mathrm{O}_{2}$ and to $44 \%$ during the breathing of $28 \% \mathrm{O}_{2}$. Though various factors, particularly the improved drainage of blocked bronchi, may have been expected to improve ventilation-perfusion relationships during the time of study, the administration of oxygen itself may have brought the improvements. Possibly the vascular reactivity of areas of the lung which are severely hypoxic may be improved by the administration of oxygen, so that the compensatory local vasoconstriction may become more effective. In contrast, Lee and Read (1967) found that inhalation of $100 \%$ oxygen by patients with chronic airway obstruction caused a deterioration in ventilation-perfusion relationships. Their patients differed from ours, however, in that they had fully recovered from episodes of respiratory infection or respiratory failure and were much less hypoxaemic $\left(\mathrm{SaO}_{2}{ }_{73-}\right.$ 97\%).

Various methods for the administration of oxygen to patients in respiratory failure have been advocated in recent years. We prefer the Ventimask because it yields an accurately known concentration in spite of varying oxygen flow and variable breathing patterns (Campbell and Gebbie, 1966; Bethune and Collis, 1967; Green, 1967; McNicol, 1967). We have confirmed in this study that oxygen therapy needs to be accurately controlled in order to avoid increasing hypercapnia. The improvement in arterial oxygen saturation with $24.5 \% \mathrm{O}_{2}$ with little or no increase in $\mathrm{PaCO}_{2}$ suggests that this regimen is effective, and is the one which should be used if serial blood gas determinations are not available. We should emphasize, however, that ideally the treatment of any patient in this situation should be controlled with measurements of mixed venous or arterial $\mathrm{PCO}_{2}$ so that any worsening of the respiratory failure can be detected early and the appropriate measures instituted.

We are grateful to Miss Helen M. Pope, Miss R. Ann Hart, and Miss Prisca Chong for technical help and to Dr. E. J. M. Campbell for advice and encouragement.

Requests for reprints should be addressed to Dr. D. A. Warrell, Department of Medicine, Hammersmith Hospital, Du Cane Road, London W.12.

\section{REFERENCES}

Bethune, D. W., and Collis, J. M (1967). Thorax, 22, 221.

Campbell, E. J. M. (1960). Lancet, 2, 10.

Campbell, E. J. M. (1965). British Medical fournal, 1, 1451. Campbell. E. J. M. (1967). American Review of Respiratory Diseases,
96, 626.

Campbell, E. J. M., and Gebbie, T. (1966). Lancet, 1, 468.

Campbell, E. J. M., and Howell, J. B. L. (1960). British Medical fournal, 1,458 .

Cotes, J. E. (1965). Lung Function. Oxford, Blackwell Scientific.

Denison, D. M. (1968). Ph.D. Thesis. University of London, Appendix 7.

Green, I. D. (1967). British Medical fournal, 3, 593.

Hutchison, D. C. S., Flenley, D. C., and Donald, K. W. (1964). British Medical fournal, 2, 1159 .

Lee, J., and Read, J. (1967). American Review of Respiratory Diseases,
96, 1173 . McNicol, M. W. (1967). Hospital Medicine, 1, 601.

McNicol, M. W., and Campbell, E. J. M. (1965). Lancet, 1, 336.

Medical Research Council (1965). Lancet, 1, 775. Mithoefer, J. C., Karetzky, M. S., and Mead, G. D. (1967). New
England fournal of Medicine, 277, 947 .

Penman, R. W. B. (1962). Clinical Science, 23, 5.

Refsum, H. E. (1963). Clinical Science, 25, 369.

Schiff, M. M., and Massaro, D. (1967). New England fournal of Medicine, 277, 950.

Sinclair, M. I., Hart, R. A., Pope, H. M., and Campbell, E. J. M. (1968). Clinica Chimica Acta, 19, 63.

Westlake, E. K., Simpson, T., and Kaye, M. (1955). Quarterly fournal of Medicine, 24, 155. 